\title{
Negotiating Alienation and marginality in the Selected Verses of Indo-Guyanese Poet Mahadai Das
}

\author{
Renuka Laxminarayan Roy \\ Assistant Professor, Department of English, Seth Kesarimal Porwal College, Kamptee. \\ ORCID: oooo-ooo2-2714-16oX. E-mail: royrenuka8o@gmail.com
}

\begin{abstract}
Indo-Caribbean literature opens a new vista of study of successful female poets and writers who have contested a literary space for themselves in the arena of West Indian literary discourse. These female writers have boldly denounced any legacy of Eurocentric literature and established their independent school of writing. The emancipation from 'colonial possessiveness', (July,1993, p. 80) (a term used by Ramabai Espinet in her writing) and a frantic effort to find new roots in the land of exile are the unique features of Indo-Caribbean literature. A rich cultural heritage, ancestral art, exotic cuisine, customs and costumes are the marks of exclusive oriental culture that is distinctly imprinted in their literature. IndoGuyanese poetess, Mahadai Das (1954-2003), a prolific poetess of South- Asian descent in her collection of poetry I want to be a Poetess of my People (1977) presents an unparalleled account of the Guyanese people's journey from immigration to independence. The episodes of violence, mutilation and physical abuse gave Indo-Caribbean female writers a new ability to articulate their woes of immigration and annihilation. The images like sailing back to India, the torments of indentureship and exile as well as racial and political turmoil in the land are interwoven together to form the prime content of their work. These female writers battle the fear of female authorship, since their voice had been long suppressed owing to the monopoly of male literary artists in the mainstream West Indian literature. The present paper proposes to study the theme of alienation and marginality as reflected in the selected verses of Indo-Guyanese writer Mahadai Das.
\end{abstract}

Keywords: Indo-Guyanese literature, immigration, racial and cultural conflict.

Literature by the Indo-Caribbean female writers has always defied the possibility of fitting into a single literary canon. Every new reading of the works by women of Indian descent in the Caribbean opens a new vista of study and exploration. Despite being obscure in nature owing to the complex ideas and experiences expressed in them, Indo-Caribbean literature offers a fertile area of reading. The genesis of literature by Indo-Caribbean female authors can be found in the history of indentureship, cultural estrangement and silencing of female voices for centuries. The female writers of East Indian communities in Caribbean have a cultural history of rich inheritance from the ancestral land of India, which was carefully preserved and consciously handed over to them by the wise ladies of their community through illustrious oral tradition of 'ajie'. The struggle of Indian women in the Caribbean has got an episodic structure; it starts with the chronicles of a long journey of excommunication of thousands of Indian coolies as indentured labourers to the Caribbean islands like Trinidad, Tobago, Guyana etc. in the first half of $19^{\text {th }}$ century. The migrated populace subsequently grappled for minimal existence in the new land, gradually established and reasserted their claim on the land. The women in Indo-Caribbean

(C) AesthetixMS 2020. This Open Access article is published under a Creative Commons Attribution Non-Commercial 4.0 International License (http://creativecommons.org/licenses/by-nc/4.0/), which permits non-commercial re-use, distribution, and reproduction in any medium, provided the original work is properly cited. For citation use the DOI. For commercial re-use, please contact editor@rupkatha.com. 
society have gained a respectable position today, since they bravely negotiated the tyrannous colonial forces and atrocious male domination in the multi-ethnic Caribbean land for a long time. The study of Indo-Caribbean literature leads us to the galaxy of successful female poets and writers who have contested a literary space for themselves in the gamut of West Indian writers. These female writers have boldly denounced any legacy of Eurocentric literature and established their independent school of writing. The emancipation from 'colonial possessiveness', (July,1993, p. 8o) a term used by Ramabai Espinet, in her writing and the frantic efforts to find new roots in the land of exile through literary contribution can be cited as the marked features of IndoCaribbean literature. Along with this, a rich cultural heritage of India, their art, cuisine, customs and costumes of exotic oriental tradition exhibit their obvious imprint on the literature of East Indians in Caribbean.

Indo-Guyanese poetess, Mahadai Das (1954-2003) is one of the most prolific poetesses of South- Asian descent in the Caribbean. Her literary contribution is significant due to its truthful portrayal of the lives of Indo-Guyanese women and their history. Through her poetry, she evokes the longings of the underprivileged people of Caribbean who were reduced to the status of 'coolies'. The term coolie has undergone several shifts in meaning: it first referred to the inhabitants of Kula (India) but was later used to designate a hired labourer. The definition was then extended to migrant workers from India and associated with indentured labourers with a negative connotation. In the Longman Dictionary of 1987, the term 'coolie' designates (esp .in India and some parts of the Far East) 'an unskilled worker', which is highly pejorative in nature.

In her collection of poems, I want to be a Poetess of My People (1977), Das presents an unparalleled account of the Guyanese people's journey from immigration to independence. The poems in this collection have strong political overtones, since in her writing she exhibited her support to PNC, a political party in the then Guyana and its political leader under whose direction Guyana was functioning. Her second anthology, My Finer Steel will Grow (1982) expresses her growing disillusionment with the Guyanese government and PNC. Her collection, Bones (1988) relates her nostalgic recollection of her cultural land Guyana during her stay in the USA. The poems in her anthology A Leaf in His Ear (2010) exhibit the writer's desperate striving to give an account of the diverse cultural and geographical heritage of Guyana. This desperation is an outcome of the urgency that she might have felt for relating the saga of trans-Atlantic exodus of thousands of Indian labourers who were brought to this land with a promise of better prospects. Her poem, 'They Came on the Ship' brings forth the experience of Indians who were brought from India to Trinidad, Tobago and Guyana in 1845. In this poetry, Das revives the trauma of transAtlantic journey imprinted in the consciousness of Indian immigrants in Caribbean. The poem delineates the story of the women who were forcibly excommunicated, dislodged and disowned from their ancestral land of India. They came to this strange island in search of better prospects and happier life. The distinctiveness of their identity was erased overnight and they were reduced to the status of contractual farm labourers, 'the coolies'. The lines from the poem are extremely significant:

They came in ships/From far across the seas/Britain, colonizing the East in India....

Westwards came the Whitby,

Like the Hesperus/ Alike the island-bound Fatel Rozack

Some came with dreams of milk and honey riches./Others came, fleeing

famine/And death,

All alike, they came —/The dancing girls,/Rajput soldiers — tall and proud 
Escaping the penalty of their pride.

The stolen wives - afraid and despondent./All alike, crossing black waters./Brahmin and Chamar alike.

They came/ At least with hope in their heart. (as qtd. in (Mahabir, 2017)

The reference to the Whitby, Hesperus and Fatel Razack are the metonymy for all those ships that brought labourers to Guyana, Trinidad and Tobago. Their reference revives the traumatic experience of these women of past horrors of hunger, deprivation and exposure to multi-racial milieu. The lines, "I remember logies/Barrack-room ranges/nigga-yards/My grandmother worked in the field./Honourable mention.", renews the pangs of being dislocated from their culture and their land. The immigrant workers were forced to accommodate in the barracks with other African labourers in the complexly alien and make-shift arrangements. Das desperately avows not to forget her links with those ancestral 'coolie' women who toiled in the farms. They suffered to retain and pass the rich legacy of Indo-Caribbean culture to the younger generations. The reference to the struggle of Indo-Caribbean women for suffrage that eased off their burden of 'coolitude' and extended them equal opportunities in Caribbean comes in the following lines: "Remember one-third quota/coolie woman./Was your blood spilled so that I might/reject my history?” (as quoted in (Mahabir, 2017)

Similar thoughts are expressed by Ramabai Espinet, another famous poet, novelist and a critic of Indo-Caribbean descent in Canada. Espinet also writes about the cultural rootedness of Indian people both in India and in the Caribbean. The protagonist in the poem, 'Hosay Night' unlocks the "rusty iron lock of memory" in the distant land of Canada. The memory of celebration of Muharram in the Caribbean island is intermingled with the memories of indentured labourers like "cutting edge of bitter cane". Although displaced and 'dishoused', these people fervently try to retain their racial and 'ethnic otherness' (2004, p. 02), the term used by Brinda Mehta in her book Disaporic Dislocation: Indo-Caribbean Women Characters Negotiate the Kala Pani. The lines: “..elephants and silks.../dhaws of Naipaul's/ Yearning not mine.” (as qtd in (Savory, July,1993, p. 8o) hint at the cultural legacy of Indo-Caribbean inherited by another literary figure Sir V. S. Naipaul. The Nobel Laureate author, initially had a problem in acknowledging his Indo-Caribbean identity and went back to his ancestral land, India. He was bitterly disillusioned with the sight of squalor in the Indian landscape and the concurrent anarchy in the Indian political scenario. He gained little consolation for his angst soul during his repeated visits to India and finally settled down in London, a place that best suited his Eurocentric sensibility. In 'Hosay Night', Espinet expresses her anxiety for the Indians in Caribbean who were excluded from the political settings of the island earlier by their colonial masters and later by the Afro-Caribbean political power.

The lives of the East Indian women in the Sugar Estates of Trinidad, Tobago and Guyana are full of violent episodes of mutilation and physical abuse. The annals of their sufferings enabled the Indo-Caribbean female writers with renewed ability to articulate their woes of immigration and annihilation. Mahadai Das's poem, 'Beast', unravels the brutal face of sexual violence that the women had to encounter during the exodus. Their physical and mental stability was greatly affected on being subjected to the vile act by the colonial masters who were alluded to as "pirates in search of El Dorado" (p.48) in the poem 'Beast'. The inhuman treatment had an enervating effect on the women; which eventually compelled them to lead a beastlike existence in the land. Here, the lines are extremely poignant: "In Gibraltar's straits/pirates in search of El Dorado/Masked and Machete bearing/ Kidnapped me/Holding me to ransom. They took my jewels/and my secrets and dismembered me.../In the cave where they kept me,/a strange beast 
grew/...and his deadly tongue,/even I was afraid of him." (Das, A Leaf in His Ear, 25th Jan 2010, p. p.48) The term, "and his deadly tongue", here refers to the ability to articulate. It refers to the poetic voice of the female folks who were ready to relate the accounts of their misery. The literary expression that they had lately achieved was earlier immature in form; yet for them, the power of articulacy was a liberating force. Das, too, feels that poetic expression can be a powerful and assertive tool of claiming one's roots in an alien land, however unpolished it may be. Das in her poem 'Unborn Child' writes about this unpolished and fragile art of her own. Here she acknowledges and celebrates this new cathartic power in herself, "I mourne unflowered words, unborn child, inside me." (Das, p. 12) Lack of promise and political uncertainty in the postcolonial Caribbean island fires a need to recount the despair of women folk in Caribbean in poetic numbers. A famous West Indian critic, Brinda Mehta rightly points out the need of self-assertion of Indo-Caribbean women in her book, Diasporic (Dis)locations: Indo-Caribbean Women Writers Negotiate the Kala Pani

Indo-Caribbean women writers have had to assert themselves in extenuating circumstances. The fact that they continue to write undauntedly, sometimes at tremendous personal cost, testifies to their sheer grit and to their determination to carve safe space of self-assertion for themselves and their sisters. (2004, p. 23)

Ramabai Espinet, too, strongly supports Das's view about the fear of female authorship which was long suppressed owing to the monopoly of male literary artists of the mainstream West Indian literary field. She calls it "the phenomenon of invisibility" (1989, p. 116)

This longing to give poetic articulation can be felt sharply due to the hitherto silencing of their voice. In her poem titled 'Bones', Das puts into words the stories of a long eclipsed history of female folks in Indian society of Caribbean. The image of 'bone' is resurrected in the poem as emblematic of the cultural heritage of Indo-Caribbean women.

"Someone should examine their story./After all, it's not that they dwindled/into dust altogether. Besides,/these bones could make more that music./They're a fire tried instrument...They have no wish to stay in the attic/They want to be part of the world." (Das, p. 18). The reference to the word 'attic' hints at Sandra Gilbert and Susan Gubar's allusion of suppressed female sexuality and equally denied feminine creative space in the mainstream literature in their book The Mad Woman in the Attic. Like Gilbert and Gubar, Das also fends for the creative space for female writers in the Caribbean literary scenario which was earlier male dominated in nature. She strongly wished that the 'cronies' in the Caribbean should get a legitimate space for themselves and for which they had long negotiated. Das, here, employs the image of 'Bone of Flute' to bring together different aspects of experiences of immigrant IndoCaribbean women. In this context Veronique Bragard gives a more insightful explanation. Her statement sheds a new light on West Indian literary aesthetics. Bragard writes: “...the bone flute which finds its origin in an Amerindian and South American legend established links with several Caribbean writers, essentially Wilson Harris, who has used the flute of bone to 're-trace' one's steps over lost ground to visualize a womb of recovery." (1998, p. 102)

The metaphor of love, longing and image of voyage can also be seen as the common features of Das's poetry. These themes are found in intermingled forms and create a mosaic of affectionate yearning of an exiled individual. The pang of being culturally and spatially dislocated forms the prime subject of some of her poems. Das's poem 'Oars' that appears in her collection of poems, Bones (1988) deals with the theme of being estranged and breached from one's mooring. "I am an Indian woman/with long hair/a band of beads/across my forehead,/I paddle against desire's deep/slow-dark river/sliding softly along/in love's canoe. (1988, p. 44) The images like 
sailing back to India, the torturing images of indentureship and exile as well as racial and political turmoil in the land are interwoven together to explore the gradual entry of these women in the social and political life of the island. The poets like Sonny Ladoo in her poem, 'No Pain like this Body', Rajkumari Singh's “Per Ajie: A Tribute to First Immigrant Woman' and Ramabai Espinet in 'A Nowhere Place' have tried to reconstruct the past that had been denied to these women. Rajkumari Singh in her poem, 'I am a Coolie', strongly gives voice to her muffled identity. In her work, she asserts her pride of being a coolie woman. Her poem, 'Per Ajie: A Tribute to the First Immigrant Woman' celebrates the status of 'Coolitude' of great grandmothers. The term 'Coolitude' was first coined by a Mauritian writer Khal Torabully, through which he gave an identity to the experiences of coolies. In 'Per Ajie', she lauds the strength and contributions of great grandmothers in carving a niche for Indo-Caribbean women in the multi-ethnic Caribbean milieu. Ramabai's poem 'An Ageable Woman' in her collection Nuclear Seasons also claims equal share and dignity for the Indo-Caribbean populace in the establishment of post-colonial Caribbean countries. She asserts that it is the hardship and perseverance of her great grandfathers that reinstated the Caribbean land. She writes: "Thus Caribbean is mine/Not because I've bought it/or bartered it/or because I sell/Trade or use it/ Or find it to be/ "A lovely piece of real estate." (Espinet, 1991, p. p.81). This lordliness comes from the affectionate attachment to the new land of thousands of Indian immigrants who claim this land as their own as a reward for their sweat and hard work.

The Indian women in the Caribbean faced social and economical stratification in the land where they were earlier looked down upon as "not the right kind of woman" (Pointing, p. 134). They were allotted the lowest paid occupation in the farm like 'weeding and cane-cutting'. They were doubly subjugated at home and outside. They were wounded and beaten at home by the men who gave vent to their frustration by resorting to 'wife beating' (Pointing, p. 135). The Indian men feeling threatened by the possibilities of miscegenation in the multi-ethnic Caribbean milieu, hurled the women further into the life of confinement and burdened them with incessant household chores. Jane Shinebourne in her novel The Last English Plantation (1988) illustrates the social and personal dilemma that Indian women in Caribbean face. Shinebourne exposes the hypocritical phallocentric Indo-Caribbean society and exploitative colonial forces that jeopardized the lives of Hindu married women in Caribbean. The difficult gender roles ascribed to the women in the traditional Indian society is well explained in the warning of Jane's mother in the novel.

...they drink rum, they just eat and drink rum in the spare time and beat their wives , and fight at the rum-shops and the weddings...Their wives cook from three o'clock in the morning to late at night. You want to be a coolie woman? Well be a coolie woman. I don't care! Coolie women have to carry all the burdens for the men, the burden of the sick, the old, the children, burying the dead, and No thanks for it, only Kicks! (1988, p. 128)

On the contrary, Das, in her poetry holds no shame for her cultural identity as a 'coolie' woman. She harps on some delicate feminine notes and romanticizes the mundane lives of the East Indian women in Caribbean. She presents them in an admiringly cultured way. In the poem, we read that they are toiling well to provide the comforts of homemade food for the men who work from morning till evening in paddy farms or in sugar estates. Her poem, 'Untitled VIII' which appears in her anthology The Leaf in His Ear presents the humdrum feminine image in a more robust tone. The speaker pays tribute to the women's morning ritual of getting ready for the day. She romanticizes the daily chores of these women and blends them with culture specific images of 'bangles', 'plaiting of hair', 'gathering of skirts' and some other playful rituals that are characteristic activities of Indian women. The speaker, here, addresses the men of the house as 
'Our lords' which hints at the strong Indian ethical values that the East Indian women in the Caribbean have zealously preserved. They have zestfully accepted the over-lordship of men as expected from them. The words like "fetching water from the well" and "burning the coals" receive a unique treatment from the author. The lines such as "Let us sling our pails/upon our arms strong rods/ and dance to the well." And "The coal will leap like joy in our hearts...Our lords will wake to hot curries and fresh baked wheat." (as quoted (Valere, 2011) have a strong Indian association that eventually establishes the ethnic identity of Indian women as devoted and selfless wives. These women seemed to have brushed aside the shame of their marginalized identity as 'coolies'. They are neither ready to mimic the anglicized way of life nor are they ready to get merged in the flux of mix-raced Caribbean culture. They are ready to come to terms with the threatened fragmentation of identity and are ready to move beyond the cultural and psychological deadlocks.

\section{REFERENCES}

Bragard, V. (1998). Gender Voyages into Coolitude: the Shaping of Indo-Caribbean Woman's Literary Consciousness.[PDF] Kunapipi, Vol. 20 (o1),(99-111).

Retrieved from https://ro.uow.edu.au/cgi/viewcontent.cgi?article=2543\&context=kunapipi

Das, M. (25th Jan 2010). A Leaf in His Ear. The University of California: Peepal Tree Publication.

Das, M. (1988). Bones. The University of California: Peepal Tree Press.

Espinet, R. (1991). Nuclear Seasons: Poems. University of Minnesota: Sister Vision Press.

Savory, Elain. (July,1993). Review: Breaking New Group, Remapping the World: Recent Writing by Caribbean Women. Journal of West Indies Literature , o6 (o1), p.8o. Retrieved from

https://www.jstor.org/stable/23019643

Espinet, R. (1989). The Invisible Woman in West Indian Fiction.[PDF] World Literature Written in English , p.116. Retrieved from

https://www.tandfonline.com/doi/abs/10.108o/17449858908589105?journalCode=rjpw19

Mahabir, R. (2017, October 30). Caribbean vocabularies of Coolitude: Guyana. Retrieved May 02, 2020, from Jacket2 Coolitude:Poetics of the Indian Labour Dispora : https://jacket2.org/commentary/caribbeanvocabularies-coolitude-guyana-o

Mehta, B. (2004). Diasporic (Dis)locations: Indo-Caribbean Women Writers Negotiate the Kala Pani. Jamaica: The University of West Indies Press.

Pointing, J. (Winter, 1986). East Indian Women in the Caribbean:Experience, Image and Voice. South Asian Women writers: The Immigrant Experience , 133-172. Retrieved from

https://www.jstor.org/stable/40872844?seq=1

Shinebourne, J. (1988). The Last English Plantation. Leeds: Peepal Tree Press

Renuka Laxminarayan Roy is currently working as an Assistant Professor in the Department of English, Seth Kesarimal Porwal College, Kamptee affiliated to Rashtrasant Tukdoji Maharaj Nagpur University, Nagpur. 